\title{
Divergent Perception: Deserts and Mountains in Transition to Modernity, Seen through Alexander von Humboldt's Views of Nature
}

\author{
Jon Mathieu
}

This chapter deals with the historical perception of two major ecosystems deserts and mountains - in transition to Western modernity. I will argue that, from $175^{\circ}$ to $185^{\circ}$, the perception underwent a process of divergence between the two systems, which is significant in its own right and can offer some clues as to general factors underlying environmental perception. Alexander von Humboldt's book Ansichten der Natur mit wissenschaftlichen Erläuterungen ("Views of Nature with Scientific Annotations") is used for illustrative and certain analytical purposes. The book, published by the author three times in different editions $(1808,1826$ and 1849), belongs to the famous pieces of nature writing of the 19th century. When it was first published, however, it received less-than-flattering reviews. A critic in the leading Göttingische Gelehrte Anzeigen stated that reading Humboldt's book had been both pleasant and instructive. Nevertheless, the gratification would have been greater if its language had been simpler. "The poetic prose seems to be unfortunate in several respects," namely for the learned audience and for the treated subjects "which are inapt to provoke poetic enthusiasm." Moreover, the author tries to establish relationships between totally different things. "To our mind, the true researching genius manifests itself not so much through the establishment of resemblances between unequal objects as through the disclosure of the characteristic features of both single objects and entire species." Instead of familiarising the audience with the plains of South America, observed in his travels, he brings them together with deserts in Asia, Africa, and even with heaths of European coastlands. This will certainly cause some readers to consider these very different surfaces as similar. ${ }^{1}$

1 Göttingische Gelehrte Anzeigen unter der Aufsicht der königl. Gesellschaft der Wissenschaften, 28 December 1809, 2049-2050, my translation from German. I use published translations when available; for Views of Nature there is a careful new American version: Alexander von 
English and French commentators believed that the reception of Ansichten der Natur was "encouraging" or even "a very flattering success" in Germany. It is not clear how the public, and different parts thereof, reacted precisely. In the long run, however, the book was read more and more as a piece of creative writing and became a literary classic. ${ }^{2}$ In the following chapter, I would like to take up the criticised points of the first moment: the form and language of the book, and the problem of a global approach to nature writing. They give relevant context information to the main question of this chapter: the general perception of deserts and mountains in the 18th and 19th centuries. Views of Nature provides a good entrance to environmental perception for several reasons. Humboldt absorbed many influences of the older literature, put them in a specific context, transformed and bequeathed them to numerous other people. His audience included important "multipliers" like Charles Darwin, Henry David Thoreau, Ernst Haeckel, George Perkins Marsh, and John Muir. ${ }^{3}$ As for the perception of deserts, my reading of Humboldt is inspired by Diana K. Davis and her thought-provoking survey The Arid Lands: History, Power, Knowledge, published in 2016. On the side of mountain perception, my own research experience goes back quite some time. ${ }^{4}$

The first section offers a succinct bibliographical inquiry of Views of Nature. The next two sections deal with the perception of deserts and mountains respectively as inferred from Humboldt and other sources. The conclusions try to bundle and analyse the historical change of environmental perception in a summary form.

Humboldt, Views of Nature, trans. Mark W. Person, ed. Stephen T. Jackson and Laura Dassow Walls (Chicago, London: The University of Chicago Press, 2014).

2 Monthly Review 59 (1809), 473; Alexander von Humboldt, Tableaux de la nature, ou considérations sur les déserts, sur la physionomie des végétaux, et sur les cataractes de l'Orénoque, trans. J. B. B. Eyriès, 2 vols. (Paris: F. Schoell, 1808), I.

3 These personalities are mentioned by Wulf in her 2015 biography; there are quite a few biographies of Humboldt, but no standard academic one: Andrea Wulf, The Invention of Nature: The Adventures of Alexander von Humboldt, the Lost Hero of Science (London:John Murray, 2015); a detailed chronology is provided by Kurt-R. Biermann and Ilse Jahn, Alexander von Humboldt: Chronologische Übersicht über wichtige Daten seines Lebens (Berlin: Akademie-Verlag, 1983).

4 Jon Mathieu, "Alpenwahrnehmung: Probleme der historischen Periodisierung," in Die Alpen! Zur europäischen Wahrnehmungsgeschichte seit der Renaissance - Les Alpes! Pour une histoire de la perception européenne depuis la Renaissance, ed.Jon Mathieu and Simona Boscani Leoni (Bern, Berlin, Bruxelles: Peter Lang, 2005); Mathieu, The Third Dimension: A Comparative History of Mountains in the Modern Era (Cambridge: White Horse Press, 2011). 
Alexander von Humboldt (1769-1859) was an intellectual celebrity in natural history from early on. It is well known that his voyage to South America from 1799 to 1804 boosted that fame in many countries. In the first three decades of the 19th century, he received more than eighty awards from learned societies and other institutions. The number of published articles, books, and illustrations is impressive. It was not only the result of Humboldt himself but also of a kind of Humboldt industry with scientific and technical assistants, independent publishing agents, translators, and intermediaries of all kinds. To date, getting an overview of the complete work and its ramifications remains difficult. In Humboldt's extensive account of the South American journey, according to his bibliographers Horst Fiedler and Ulrike Leitner, it is not even possible always to identify the affiliation to the various series of his work. The publication started in 1814 and was discontinued in 1831, with only a third of the travel route described. For the breach of contract Humboldt had to pay a heavy penalty to his publisher in Paris, whom he called "my tyrant" in a letter to his German publisher Georg von Cotta. ${ }^{5}$

Views of Nature belonged to the decidedly popularising parts of Humboldt's work, and Cotta - the publisher of Johann Wolfgang Goethe, Friedrich Schiller and other foremost poets and intellectuals - was its cornerstone. While the editions of 1808, 1826 and 1849 varied in size and contents, the Cotta family remained unchanged. Possibly the very idea came from that side. The 1808 edition consisted of the publication of three academic lectures about arid lands, plant physiognomy, and a particular South American waterfall, delivered by Humboldt to the Royal Prussian Academy of Sciences in Berlin in 1807 and 1808. He completed the text of these oral presentations with endnotes, called "annotations and additions" ("Erläuterungen und Zusätze"). One of the essays was a reprint from a prior separate publication. The small format booklet was designated as "first volume" on the title page, and the last page announced the

5 Horst Fiedler and Ulrike Leitner, Alexander von Humboldts Schriften: Bibliographie der selbständig erschienenen Werke (Berlin: Akademie Verlag, 200o), XVI, 70; a quantitative chronological approach to Humboldt's publications and awards in Jon Mathieu, "Von den Alpen zu den Anden: Alexander von Humboldt und die Gebirgsforschung," in Wissenschaft - Berge Ideologien. Johann Jakob Scheuchzer (1672-1733) und die frühneuzeitliche Naturforschung Scienza - montagna - ideologie. Johann Jakob Scheuchzer (1672-1733) e la ricerca naturalistica in epoca moderna, ed. Simona Boscani Leoni (Basel: Schwabe, 2010), 308; Oliver Lubrich, ed., Alexander von Humboldt: Das graphische Gesamtwerk (Darmstadt: Lambert Schneider, 2014) offers a complete edition of the illustrative work; his low figures of the book production (p. 750) do not include the numerous derivative prints. 
"end of the first volume." A second volume, however, did not appear. Probably there had been a plan to include other essays, which was then abandoned. ${ }^{6}$ The realisation came nearly twenty years later in the 1826 edition. Without a new preface, the three original texts were now rearranged and completed with two new ones: a lecture about volcanoes, read in 1823 to the same Academy in Berlin, and a narration about the "Life Force" published back in 1795 in a literary journal attended by Schiller. Since 1846, then, Cotta and Humboldt discussed plans for a third edition. Humboldt should redo the annotations. Surprisingly, after that extensive revision work, the busy elderly naturalist came up with two new essays about his South America travel almost half a century ago, one about the nocturnal wildlife in the rainforest, the other one about the Andes. ${ }^{7}$ Table 9.1 gives a survey of the titles and the formal organisation of these three first-hand German editions.

TABLE 9.1 First-hand German editions of Views of Nature: bibliographical indications

\begin{tabular}{|c|c|c|c|c|}
\hline $\begin{array}{l}\text { Edition } \\
\text { Publisher }\end{array}$ & $\begin{array}{l}\text { Essays } \\
\text { Title (pages) }\end{array}$ & $\begin{array}{l}\text { Endnotes } \\
\text { (pages) }\end{array}$ & Number & $\begin{array}{l}\text { Volumes } \\
\text { Total pages }\end{array}$ \\
\hline \multirow{4}{*}{$\begin{array}{l}18 \circ 8 \\
\text { Tübingen: } \\
\text { J. G. Cotta }\end{array}$} & o. Preface (v-VIII) & - & - & 1 vol. \\
\hline & $\begin{array}{l}\text { 1. Concerning the Steppes and } \\
\text { Deserts }(1-46)\end{array}$ & $(46-155)$ & $5^{\circ}$ & $\begin{array}{l}\text { designated as } \\
\text { "first volume" }\end{array}$ \\
\hline & $\begin{array}{l}\text { 2. Ideas for a Physiognomy of Plants } \\
(157-204)\end{array}$ & $\left(205^{-278)}\right.$ & 36 & 334 pages \\
\hline & $\begin{array}{l}\text { 3. Concerning the } \\
\text { Waterfalls of the Orinoco near } \\
\text { Atures and Maypures }(281-330)\end{array}$ & $\left(33^{1-}-334\right)$ & 7 & \\
\hline
\end{tabular}

6 In the French version of the 1808 edition, the first essay was augmented by a letter and published as volume 1, the other two essays as volume 2 . The translation was concluded only half a year after the German manuscript (Fiedler and Leitner, Alexander von Humboldts Schriften, $39,51)$; this could mean that it was rather quickly clear that the announced second volume in German would not follow.

7 Fiedler and Leitner, Alexander von Humboldts Schriften, 37-42. 
TABLE 9.1 First-hand German editions of Views of Nature: bibliographical indications (cont.)

$\begin{array}{llll}\text { Edition } & \text { Essays } & \text { Endnotes } & \text { Number } \\ \text { Publisher } & \text { Title (pages) } & \text { (pages) } & \text { Total pages } \\ & & & \end{array}$

1826

Stuttgart,

Tübingen

J. G. Cotta

1849

Stuttgart,

Tübingen:

J. G. Cotta o. Preface to the First Edition (v-VI)

1. Concerning the Steppes and Deserts (1-45)

2. Concerning the Waterfalls of the

Orinoco near

Atures and Maypures (183-230)

3. Ideas for a Physiognomy of Plants (1-47)

4. Concerning the Structure and Action of Volcanoes in Various Regions of the Earth (126-178)

5. The Life Force, or The Rhodian Genius (187-200)
2 vols. vol. 1: essays $1-2$ vol. 2: essays $3-5$ 434 pages
$(46-180) \quad 5^{\circ}$

$\left(23^{1-234)} 6\right.$

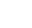

2 vols.

vol. 1:

essays $1-4$

vol. 2:

essays $5^{-8}$

744 pages

2. Concerning the Waterfalls of the

$(287-316) \quad 12$

Orinoco near Atures and Maypures (249-286)

3. The Nocturnal Wildlife of the $\left(33^{8-340)} \quad 6\right.$ Primeval Forest (317-337)

4. Hypsometric Addenda (341-35o)

5. Ideas for a Physiognomy of Plants $(1-41)$

6. Concerning the Structure and $(290-296) \quad 3$ Action of Volcanoes in Various Regions of the Earth (249-289) 
TABLE 9.1 First-hand German editions of Views of Nature: bibliographical indications (cont.)

\begin{tabular}{llll} 
Edition & Essays & Endnotes & Number \\
Publisher & Title (pages) & (pages) & Total pages \\
\hline
\end{tabular}

7. The Life Force, or The Rhodian $\quad(309-314) \quad 1$

Genius (297-308)

8. The Plateau of Cajamarca, the Old $\quad(368-394) \quad 20$

Residential City of Inca Atahualpa;

First Sight of the Pacific from the

Ridge of the Andes Chain (315-367)

SOU RCES: Humboldt, Ansichten der Natur mit wissenschaftlichen Erläuterungen (1808, 1826, and 1849); English titles of the essays according to the 2014 translation; in the originals, the essay about the "Life Force" has a subtitle: "Eine Erzählung" (a narration).

From the bibliographical indications, it is evident that Views of Nature experienced notable growth from 1808 to 1849. It grew from three essays on 334 small format pages to eight essays on 744 bigger pages. Growth was most noticeable at the annotation level. The proportion of endnotes in the total essay text increased from 71 to 85 percent in the piece on arid lands, from 61 to 83 percent in the botanical essay, and from 8 to 44 percent in the waterfall essay. Interestingly, the number of endnotes did not go up very much. The three original essays received only between two and five supplementary notes. This indicates that the "annotations and additions" had fixed entry points, which would then be filled in with new results from ongoing research. There was no oneto-one, flexible relation between the two levels of text. The essays, originally written for oral presentation, remained relatively stable, while the annotations changed from one edition to the next. In the essay on arid lands, for example, the annotations offered about sixty references in 1808 . In the 1826 edition there were more than ninety, particularly new self-references to Humboldt's main publications. The 1849 edition, then, brought another huge increase in references, both to cutting edge research and in the self-referencing mode. The new supplementary notes deserve special attention. In essays 5 and 7 , they defend a field of research considered outdated (Physiognomy of Plants), and an older combination of literature and science (Life Force). The supplementary notes in the arid lands essay offer new information about the Sahara and the steppe 
vegetation, revealing by contrast that Humboldt did not consider the preceding editions strong in these matters. ${ }^{8}$

A good indicator of the public attention attracted by Views of Nature is provided by its translation history. The 1808 edition was rendered completely into French and Dutch, while the 1826 edition had only a complete French translation. Very different was the situation in 1849 when the possibility of selling nonGerman versions of the illustrious scholar's popularising work prompted fierce competition between publishers both in France and in Britain. It resulted in two rival translations respectively. Perhaps a similar pattern manifested itself a bit later in Russia with one translation in 1853 (except for essay 7) and another one in $1855 .{ }^{9}$ Table 9.2 presents the complete and partial translations during Humboldt's lifetime in a survey format.

TABLE 9.2 Translations of Views of Nature from the German editions until Humboldt's death 1859

\section{Edition Language:Translator Year Index Illustration Comments}

\begin{tabular}{|c|c|c|c|c|c|}
\hline \multirow[t]{4}{*}{$18 \circ 8$} & French: J. B. B. Eyres & 1808 & - & - & $\begin{array}{l}\text { Includes additional } \\
\text { item }\end{array}$ \\
\hline & Italian: anonymous & 1808 & - & - & Only part of essay 1 \\
\hline & Dutch: G. Troost & $18 \circ 8$ & - & - & \\
\hline & Russian: anonymous & 1818 & - & - & Only essay 1 \\
\hline \multirow[t]{3}{*}{1826} & French: J. B. B. Eyres & 1828 & - & - & \\
\hline & Polish: anonymous & $1828 / 43$ & - & - & Only essays 4 and 1 \\
\hline & Russian: anonymous & 1829 & - & - & Only essay 5 \\
\hline \multirow[t]{7}{*}{1849} & English: E. J. Sabine & 1849 & DC, ID & - & Rival translation to Otté \\
\hline & English: E. C. Otté & $185^{\circ}$ & DC, ID & $1 \mathrm{IM}$ & Rival translation to \\
\hline & & & & & Sabine \\
\hline & French: F. Hoefer & $185^{\circ} / 5^{1}$ & $\mathrm{DC}$ & $4 \mathrm{IM}, 2 \mathrm{MP}$ & Rival translation to \\
\hline & & & & & Galusky \\
\hline & French: Ch. Galusky & $185^{1}$ & $\mathrm{DC}$ & $5 \mathrm{MP}, 2 \mathrm{FG}$ & Rival translation to \\
\hline & & & & & Hoefer \\
\hline \multicolumn{6}{|c|}{8 Humboldt, Views of Nature, $77-82,238-41,264-66}$. \\
\hline \multicolumn{6}{|c|}{$\begin{array}{l}9 \text { Fiedler and Leitner, Alexander von Humboldts Schriften, 61; being unable to read Russian, I } \\
\text { cannot check that point. }\end{array}$} \\
\hline
\end{tabular}


TABLE 9.2 Translations of Views of Nature from the German editions (cont.)

\section{Edition Language:Translator Year Index Illustration Comments}

$\begin{array}{lllll}\text { Dutch: E. M. Beima } & 1850 & \text { DC } & - & \\ \text { Russian: N. Ch. Ketčer } & 1853 & \text { DC } & - & \text { Without essay 7 } \\ \text { Russian: A. Nazymov } & 1855 & (?) & \text { IM } & \text { Complete translation } \\ \text { Czech: Vojtěch Šafařík } & 1859 & - & - & \text { Only part of essay 3 }\end{array}$

DC: detailed table of contents; ID: alphabetical index; IM: image; MP: map; FG: figure; (?): unsettled. The numbers of the essays correspond to the respective edition, see table 9.1. SOURCE: Fiedler and Leitner, Alexander von Humboldts Schriften, 50-63 and available online versions; I thank Oliver Lubrich for providing me the Russian version of 1853 .

The table includes indications on the make-up of the books and shows that the translations of the 1849 editions differed quite significantly from the earlier ones. Some of them were now illustrated with images, maps, and figures. And most, if not all, possessed a detailed, summarising table of contents which helped the readership through the various and sometimes surprisingly diverse essays. The translations were taken from the German 1849 edition, which offered - in contrast to earlier editions - an extensive survey of about a dozen pages in each volume. The British translations went a step further and included an alphabetical index. Humboldt did not believe that Views of Nature could receive much attention with an English audience. In a letter to a friend, he noted that the book, although he had enriched it with a lot of science, was completely aimed to the "German way of feeling" ("deutsche Gefühlsweise") and that the English were more rigorous in this matter. Shortly after, however, he remarked that the English version was better received than expected. Indeed, the translation by E. J. Sabine was reprinted in three further editions after $1849 \cdot{ }^{10} \mathrm{~A}$ notable feature of later editions concerns the relationship between the essays and the scholarly annotations. While the latter had been extended considerably during the first half of the 19th century, in the 2oth century they were scaled back. A popular German edition, first published in 1969, included an extremely flattering postscript on the prominent compatriot and completely removed the annotations in which the very same person

10 Alexander Humboldt, Briefe von Alexander von Humboldt an Christian Carl Josias Freiherr von Bunsen (Leipzig: Brockhaus, 1869), 115-16, 119; Fiedler and Leitner, Alexander von Humboldts Schriften, 46-47. 
had invested a great deal of effort. The latest American edition is more respectful skipping the scholarly part only in the title, not in the contents. ${ }^{11}$

Our main purpose here is to employ Views of Nature as a starting point to shed light on the perception of deserts and mountains. The particular form of two parallel texts is very appropriate. Whereas the essay level leans towards subjectivity, emotional expression and solemn literary language, almost cleansed from references, the annotation level is on the objective side with a more value-neutral outward look. Together, the two levels reflect a broad spectrum of environmental discourses and attitudes. Humboldt was quite conscious of the difficulties of the "dual direction of this text" which he sketched in the last preface as "a painstaking effort to heighten the enjoyment of Nature through living depictions, while simultaneously increasing insight into the harmonious cooperative effect of forces according to the state of scientific understanding of the time." In the first preface the difficulties were highlighted with an ostentatious self-critique. "In appealing to feeling and fancy," Humboldt wrote in 1808 , "style easily degenerates into poetic prose," of which the following pages, regrettably, would offer manifold examples. ${ }^{12}$ As we have seen, this point was taken up by a German reviewer criticising the high-tone literary style. An English reviewer disliked the dual organisation. According to him, Humboldt should have "moulded his materials into one uniform and consistent mass, instead of detaching such a large and valuable portion of them into the form of supplementary annotations."13

For Humboldt's career, playing two games at the same time was probably helpful, particularly in Germany. Besides showing his qualities as a naturalist, it positioned him near the distinguished world of poets. Moreover, the use of his native tongue instead of the dominant French language was advisable for political reasons. For a Prussian and indeed a chamberlain of the Prussian King, the creation period of Views of Nature was troubled. On 27 October 1806, Napoleon entered Berlin after his victory in two battles. On 29 January 1807 , Humboldt read the first lecture about arid lands leading to his book. When the book was in print one year later, the Grande Armée was still in town. Humboldt's preface reflected the situation in an allusive yet unmistakable way: "To embattled minds particularly, these pages are dedicated. 'Who saves himself from

11 Alexander von Humboldt, Ansichten der Natur, ed. Adolf Meyer-Abbich (Stuttgart: Reclams Universal-Bibliothek, 1969); Humboldt, Views of Nature.

12 Humboldt, Views of Nature, 25, 27; see also Thomas Richter, Alexander von Humboldt: "Ansichten der Natur". Naturforschung zwischen Poetik und Wissenschaft (Tübingen: Stauffenburg, 2009), 58-66.

13 Göttingische Gelehrte Anzeigen, 2049-50; Monthly Review, 474-75 (about the 1808 French version). 
life's stormy wave' will follow me gladly into the thickets of the forest, into the immeasurable steppes, and out upon the spine of the Andes range."14

\section{$3 \quad$ Perception of Deserts}

In the first essay of Views of Nature, Humboldt recalled travel impressions of the steppe-like Llanos in Venezuela, which he visited in 180o, and then proceeded to global comparisons. While the preface promised his readers "enjoyment of Nature," here they had to be content with dark scenery and dramatic animal fights. The entrance to the semi-arid lands is depicted as a transition to another world: "From the luxuriant fullness of organic life, the astonished wanderer comes to the barren edge of a sparse and treeless desert. No hill, no cliff rises as an island in this incalculable space." The unbounded space reminds the wanderer of an ocean, and both steppes and oceans provide a feeling of infinity. "But while the clear ocean surface in which ripples the graceful, softly foaming wave is a friendly sight, dead and stiff lies the steppe, stretched out like the naked rocky crust of a desolate planet." This entrance sets the tone for the rest of the essay. Arid lands are dismal areas with few or no people. They constrict the mood of the visitor. Everywhere drought announces death. The Sahara, in particular, is a "terrible sea of sand." And shepherd populations can be dangerous. The Mongols and other peoples have brought "calamity and devastation across the globe." More precisely: "Over the course of the centuries, whenever early intellectual culture has travelled like revitalizing sunlight from east to west, so too have barbarism and rawness of custom subsequently threatened to creep over Europe like a fog."15

Humboldt's 1800 journey across the Llanos lasted two and a half weeks. Probably this short "desert" experience was one of the reasons that his essay was comparative and based on literature to a large degree. The method was described as both productive and demanding: "It is a rewarding (if difficult) exercise in general regional geography to compare the natural properties of remote regions to one another and to describe the results of this comparison in concise terms." The German reviewer of 1808 , quoted above, believed that the exercise was misleading, not rewarding, in this case. The arid or semi-arid areas across the globe, included in Views of Nature, were too diverse for useful analysis. ${ }^{16}$ These methodological tensions between generalising and individualising

\footnotetext{
14 Humboldt, Views of Nature, 25.

15 Humboldt, Views of Nature, 29-31, 34, 36-38.

16 Humboldt, Views of Nature, 33; Göttingische Gelehrte Anzeigen, 2049-50.
} 
approaches accompanied Humboldt throughout his life. It is known that the global perspective remained central to his thinking and his success. When speaking of a specific scholarly style - a "Humboldtian Science" - historians insist on his planetary research strategy. ${ }^{17}$ With the booming production of world atlases involving Humboldt's support, or only his name, that aspect received a visual expression. For the problem of aridity, for example, readers could refer a global map of precipitation in Berghaus's Physikalischer Atlas. ${ }^{18}$ The Views of Nature allude repeatedly to the methodological tension. In the essay on volcanoes, added to the 1826 edition, Humboldt shows how the scholarly focus on the small volcanoes Vesuvius and Etna had produced erroneous assumptions - to be corrected by the inclusion of the huge volcanoes in South America and other parts of the world. In the essay on nocturnal wildlife in the rainforest, added to the 1849 edition, he reflects on the relationship between language and "natural truth" ("Naturwahrheit"). In contrast to the other strategy, a "limiting individualization" ("beschränkende Individualisierung”) is presented as suitable to achieve natural truth. ${ }^{19}$

In her recent survey on The Arid Lands, desert ecologist and historian Diana K. Davis points out that Humboldt, from the first to the second edition, made a seemingly small yet significant change in Views of Nature. When describing the African situation, he added a further element to the conditions of the "terrible sea of sand," highlighted here with italics: "Associated with the effect of hot land breezes in Africa, to the extent that we are familiar with it, is the lack of large rivers, of forests that exhale water vapor and create a cooling effect, and of high mountains." Humboldt did not change the text level of his book easily. In this case, after 1808 , he must have seen that forests should be mentioned in the desert context as a counteracting force. ${ }^{20}$ For explanation, Davis refers to a generalising passage in his travel account about Venezuela, published in 1819: "By felling the trees that cover the tops and the sides of mountains," Humboldt asserts, "men in every climate prepare at once two calamities for future generations; the want of fuel and a scarcity of

17 See e.g. Susan Faye Cannon, Science in Culture: The Early Victorian Period (New York: Dawson, 1978), 73-10o.

18 Heinrich Berghaus, Physikalischer Atlas zu Alexander von Humboldt, Kosmos. Entwurf einer physischen Weltbeschreibung, ed. Ottmar Ette and Oliver Lubrich (Frankfurt am Main: Eichborn, 2004, 1st edition 1845-1848), 20-21.

19 Humboldt, Views of Nature, 141-42, 243-46.

20 Diana K. Davis, The Arid Lands: History, Power, Knowledge (Cambridge MA: The мIт Press, 2016), 82-86; Humboldt, Views of Nature, 34, with Alexander von Humboldt, Ansichten der Natur mit wissenschaftlichen Erläuterungen (Tübingen: J. G. Cotta'scher Verlag, 18०8, 1st edition; Stuttgart: J. G. Cotta'scher Verlag, 1826, 2nd ed.), 18. 
water." Trees cool down the climate and diminish the evaporation of soils by sheltering them from the sun. When forests are destroyed the springs dry up or become less abundant. The dry beds of rivers are converted into torrents whenever great rainfalls commence which, in turn, causes erosion and inundations. Hence, the destruction of forests, the want of permanent springs and the existence of torrents are three closely connected phenomena. For proof, Humboldt refers to the Alps and the study of a director of the École nationale des ponts et chaussées about floods in the Po Valley. ${ }^{21}$

Davis puts the Humboldtian account, and its change, into a long-term approach to the perception of deserts in the West. Her centrepiece is the politically driven colonial assumption that arid regions had been laid waste by "traditional" forms of land use. Originally - it was assumed - the regions had been covered and cooled down by forests. However, "barbarous" mobile forms of pastoralism turned them into the "desolate" arid state which the colonial officers found in North Africa and elsewhere, and which should be recovered by "improvement" through European style agriculture or "reforestation." In the Christian tradition, deserts had been ambivalent spaces of temptation and deception, or of perfection as with the monastic movement of the "Desert Fathers" of the 3 rd and 4th centuries. But they were mostly considered a simple fact of life on earth - not a degenerated part - in continuation of classical views. During the early modern period, when European powers expanded and scholarly discourse intensified, the association between changes of landscape and climate grew in importance and enhanced the assumed role of human action in environmental transformation. By the mid-18th century, the desiccation belief formed a rather coherent ensemble of thought: arid lands have been abused through deforestation producing a decrease in rainfall and hence the necessity of restoration. During the 19th century, then, this belief dominated policies in Europe and the colonies to a considerable degree. Some of the policies were socially repressive and ecologically damaging. Recent arid area research has shown that the variability of precipitation and the long-term sustainability of pastoralism have been clearly underrated by enlightened, colonial and postcolonial scholarship. ${ }^{22}$

21 Alexander von Humboldt and Aimé Bonpland, Personal Narrative of Travels to the Equinoctial Regions of the New Continent During the Years 1797-1804, vol. 4 (London: Longman, Hurst, Rees, Orme, and Brown, 1819), 142-43; the footnoted French author was Gaspard de Prony.

22 Davis, The Arid Lands: History, Power, Knowledge, chapters 2-4; see also Diana K. Davis, Resurrecting the Granary of Rome: Environmental History and French Colonial Expansion in North Africa (Athens OH: Ohio University Press, 2007); Davis, "Deserts," in The 
When Humboldt put forward a desolate image of deserts in 1808 , and added a forest element thereto in 1826 , he was in line with ideas of his time, particularly in France. During his long stay in Paris (1808-1827), he maintained close contact with leading persons in academia and administration. It is quite probable that he knew François Antoine Rauch, chief of service in the department Ponts et chaussées. Rauch's work gives a telling example of the desiccationist approach in this milieu. ${ }^{23}$ In 1792 , the engineer and geographer, inspired by the Revolution, published his first plan for reform including elements of deforestation fear and sent it to politicians in Paris and all over France. Ten years later he came up with a two-volume work programmatically entitled Hydro-Vegetal and Meteorological Harmony, or Research into the Means of Recreating with our Forests the Strength of the Temperatures, and the Regularity of the Seasons, by Reasoned Plantations (my translation from French). In 1818, Rauch published an augmented version of his work. While the 1802 edition had 675 pages and was dedicated to the "Citoyen Premier Consul" (Napoleon), the latter version extended to 9oo pages with a dedication to "all the Sovereigns and all the Governments." The First Consul was addressed with the following words: "Rome has only be great and illustrious under its consuls. France, restored by your military genius, shining of glory, from the ruins of the most astonishing Revolution ever happened in the annals of humankind, enters the consulate lustres in view of a most brilliant destiny!" After a few sentences, then, Rauch came to the point and stated that "our beautiful mountains" ("nos belles montagnes") have lost their majestic forests that protected them from devastation. Chapter 1 instructed the readers in general terms on the benign effects of woods. Chapter 2 presented a panorama of the sad effects of deforestation observed in Asia and Africa and of the alarming signs in Europe. ${ }^{24}$

Oxford Handboook of Environmental History, ed. Andrew C. Isenberg (New York: Oxford University Press, 2014).

23 Rauch's 1802 book is discussed by Davis, The Arid Lands: History, Power, Knowledge, 64-69; a direct link to Humboldt cannot be shown so far.

24 François Antoine Rauch, Harmonie hydro-végétale et météorologique, ou recherches sur les moyens de recréer avec nos forêts la force des températures et la régularité des saisons, par des plantations raisonnées, 2 vols. (Paris: Levrault 1802); Raphaël Larrère, "Les utopies de François Antoine Rauch: ou comment sortir de la physiocratie, tout en maintenant l'homme dans la nature," in Nouvelles sciences: modèles techniques et pensée politique de Bacon à Condorcet, ed. Franck Tinland (Seyssel: Champ Vallon, 1998). 
Nos belles montagnes - Rauch was one of many administrators in France who wanted to restore them by extending their forest cover. Drawing on earlier discourses, during the first half of the 19th century, the general concept emerged that the mountains of the nation should belong to forests as the plains to agriculture. According to the concept, mountain torrents damaged the plains, and were caused by using slopes for pasturing animals, not for cultivating trees (studies of our time would show that extraordinary rainfalls played the dominant role). Non-forested mountain stretches were considered a recent phenomenon, produced by an ignorant, predatory peasantry (in reality they went back to early modern and medieval population processes). An alarmist atmosphere called for state intervention by pushing the peasants off their communal lands and claiming them for the national territory. In a first period, things took their course by legislation and by trying to enforce laws with a militarystyle administration. Afterwards active reforestation in often rough mountain territory was institutionalised. A national forest code passed in 1827 , and a special Alpine reforestation law in 186o. Administrative wisdom (in contrast to contemporary botanical knowledge) did not suggest that reforestation could be a problem above a certain altitude. It seemed possible everywhere, except for the rocky summits. According to a detailed study of Tamara L. Whited, mountain peasants tried to resist these inroads right from the beginning in many ways. She compares the Alpine situation to French colonial politics in Algeria. The battles between state power, obsessed with forest ideology, and dry-land pastoralists had striking parallels, yet the intervention was much harsher in subdued North Africa. ${ }^{25}$

As mentioned above, Humboldt was in line with many enlightened ideas about forests in desert and mountain contexts. However, he did not blame pastoralists for deforestation in Views of Nature, and perhaps would have been opposed to the crude policies of the late 19th century. But he was not interested in the two ecosystems in the same way: the arid zones attracted him for some time, whereas he had a lifelong affair with mountains. ${ }^{26}$ It started with a study at the mining academy in Saxony (1791), continued with the appointment as a mining inspector $\left(179^{-1796)}\right.$ and several visits to the Alps (1792, 1795, 1797-1798), and climaxed with his attempt to reach the top of the Chimborazo

25 Tamara L. Whited, Forests and Peasant Politics in Modern France (New Haven: Yale University Press, 200o), particularly 53-67, 199-211; see also Davis, Resurrecting the Granary of Rome, 72-79.

26 Mathieu, "Von den Alpen zu den Anden”; Mathieu, The Third Dimension, 23-32. 
volcano in Ecuador, believed to be the highest summit of the world (1802). In spite of Humboldt's varied interests, the upland image stuck to him for decades. A famous portrait, painted in the year of his death, shows him as an old man in front of Chimborazo. ${ }^{27}$

Interestingly, in Views of Nature, the principal mountain plot is to be found at the annotation level and is very much centred on measuring elevation above sea level. The reader can participate in the expanding quantitative description of the world's third dimension. In the 1849 edition, this speciality of Humboldt remained no longer confined to endnotes, but emerged also at the upper essay level as Hypsometric Addenda (see table 9.1). During the forty years between the first and the third editions, the Chimborazo, step by step, lost its former position as the highest summit. After his return from South America, Humboldt announced by personal letter to the King of Prussia that he had climbed "the highest mountain ranges of the world, the Cordilleras de los Andes." ${ }^{28}$ In 1808, in spite of opposite views, he still defended that opinion. He described how he had measured the Andean summit, and maintained that the "Himalah" mountains in Asia could perhaps be only slightly higher than the Etna in Sicily. By 1826, it was clear that the Asian mountain ranges surpassed the Andes. Humboldt, based on more information, distinguished four of them; perhaps "Pic Dhawalagiri" was their highest summit. In 1849, he included North America in his account, and for South America he had now more comprehensive reports, showing that even there, things had changed. According to Robert Fitz-Roy and Charles Darwin, the explorers on HMs Beagle, Aconcagua was the top Andean summit. ${ }^{29}$ Thus globalisation was both a blessing and a curse for Humboldt. His dreams of measuring the planet were realised with the work of followers, relativising by the same action his own physical achievement of 1802 .

On the side of environmental "enjoyment," Humboldt's book offers two mountain views. The first was rather conventional and adopted the emphatic language of the European enlightenment and romanticism. "In the mountains is freedom! The breath of the tomb / Cannot climb up to the purest air's home, /

27 By Julius Schrader, today in the Metropolitan Museum of Art, New York.

28 Otto Krätz, Alexandervon Humboldt:Wissenschaftler - Weltbürger-Revolutionär (Munich: Callwey Verlag, 1997), 182.

29 Humboldt, Ansichten der Natur mit wissenschaftlichen Erläuterungen, 75-77, 208-12 (1808); 10-96 (1826, vol. 1); 6o-72, 149-53 (2014 (1849)); at the end, Humboldt did not find mountaineering really important anymore: "Unfortunately, as I develop more completely in another work, these mountain expeditions beyond the line of everlasting snow (as much as they capture the imagination of the public) are of very little scientific value!" (ibid., 172). 
The world is perfect anywhere, / If Humanity's anguish has not entered there." Humboldt borrowed these verses from a drama of Schiller, published five years earlier, and offered them in the preface to the "embattled minds" of the readers to distract them from political sorrows (see section 2). When appealing to landscape painting or to personal experience of his audience, the conventionality of this kind of mountain imagery becomes particularly clear. Humboldt refers to the "Swiss Nature" model of landscaping, and presents, in another work, a picture of the Chimborazo with hints to the Alps: "The travellers who have seen from near the summits of Mont-Blanc and of Mont-Rose are the only ones capable of appreciating the character of this impressive, calm and majestic scenery" 30 The second view went beyond that restricted European experience and consciously stressed the restriction. Humboldt believed that the "enjoyment of Nature" was enhanced by biological and physical diversity. Steppes and deserts were mostly monotonous, while the highest degree of diversity was offered by tropical mountains, his favourite ecosystem. Vegetation in this zone was most lush, and the vertical botanical succession provided further enrichment. ${ }^{31}$

The social conventions of decidedly positive attitudes towards mountains, adopted and enlarged by Humboldt, emerged in the second half of the 18th century. The new attitudes did not come out of nowhere. In earlier periods the mountain imagery was often ambivalent, with shifting mixtures of negative and positive elements. After 1750, the rise of enlightened ideas in leading sections of the European societies prompted a relative increase of positive elements, and above all, a massive increase in the attention devoted to mountains. They were now seen as an embodiment of nature with which society should reconcile. In a first period the move to the mountains, and particularly to the European Alps, had been sustained by naturalists. Later on, other travellers and cultural protagonists joined them, leading to the birth of nature tourism. The current vocabulary for mountain scenery offered a panoply of adjectives, ranging from "picturesque" and "romantic" to "grand" and "sublime." The discourse about grand and sublime nature often had spiritual overtones. A certain

30 Humboldt, Views of Nature, 160; Alexander von Humboldt, Vues des Cordillères, et Monumens des Peuples indigènes de l'Amérique (Paris: F. Schoell, 1810), 200 (it is the picture reproduced in the English edition, figure 3).

31 See e.g. Humboldt, Views of Nature, 167-69; in his late work Cosmos, Humboldt integrated this view in an approach to a theory of environmental perception, see Alexander von Humboldt, Kosmos: A General Survey of the Physical Phenomena of the Universe, vol. 1 (London: H. Baillière, 1845), 6-16. 
sacralisation was one of the tendencies within this modern aesthetic, emotional view of mountains. ${ }^{32}$

How far did the ennoblement of nature by "sublimity" extend? Mountains were included from the beginning; and so, certainly, were seas and oceans. ${ }^{33}$ But what about arid zones - did they deserve the title? Diana K. Davis mentions the restricted possibility of the desert sublime. In the Christian tradition, certain positive opinions went back to the "Desert Fathers" and their monastic asceticism (see section 3). According to circumstances, positive images could appear occasionally also after the spread of the desiccationist paradigm. In the early 2 oth century, a group of idealistic British, taken in by the mysterious world of "Arabia," for a while romanticised the local nomads instead of blaming them for a barbarous and damaging way of life. ${ }^{34}$ Another interesting case in point concerns the integration of the Far Western landscape of the United States in the repertoire of her national culture. In a first moment, environmental perception in North America depended heavily on European aesthetic ideals. The parched, arid regions of the Southwest did not fit into these categories. Explorers spoke of "dreary," "dismal," even "revolting” regions. It was only around the turn of the 2oth century when perception changed and some of these lands, judged by new standards, became popular and celebrated. ${ }^{35}$

\section{$5 \quad$ Conclusions}

Environmental perceptions are often formed by an overlay of older and newer images. They are mostly of different intensity. Some of them can be considered social conventions or fashions, some leave more space for individual attitudes. Thus, complexity seems to be the rule in many regards. Nonetheless, it is important to delineate the main historical trajectories in the understanding of nature. This chapter has argued that the perception underwent a process of divergence between deserts and mountains in the transition to Western

32 Jon Mathieu, "The Sacralization of Mountains in Europe during the Modern Age," Mountain Research and Development 26, no. 4 (2006); there are quite a few recent accounts of the history of mountain imagery; most of them dismiss the earlier black-andwhite approach (change from absolute negative to absolute positive images).

33 John Mack, The Sea: A Cultural History (London: Reaktion Books, 2011), 95-99.

34 Davis, The Arid Lands: History, Power, Knowledge, 38-39, 115-16; see also Yi-Fu Tuan, "Desert and Ice: Ambivalent Aesthetics," in Landscape, Natural Beauty and the Arts, ed. Salim Kemal and Ivan Gaskell (Cambridge, New York: Cambridge University Press, 1993), $145^{-46 .}$

35 Anne Farrar Hyde, An American Vision: Far Western Landscape and National Culture, 18201920 (New York: New York University Press, 199o). 
modernity. Up to the mid-18th century, the two major ecosystems, in public discourse, were both considered ambivalent spaces with no truly generalised values attached. Later, when "modernity" took command, deserts were clearly devalued and mountains clearly elevated. The process of divergence can be roughly fixed to the period between 1750 and 1850 or 1900 .

For analytical reasons, in this discourse, we can discern technical (or technocratic) and aesthetic (or culturalist) directions and arguments. They were driven by population and economic growth, state-building, political expansion, and intensification of research and education in the 18th and 19th centuries. The two directions can be considered analogous to the two directions of Humboldt's Views of Nature. This book, published in a rather improvised manner in 1808 and augmented and revised in 1826 and 1849 by the author, comprised two parallel texts: the essays were written in an aesthetic literary style with numerous valuing adjectives, whereas the endnotes included long and rather technical information about the landscapes, plants, animals and cultural monuments described. This double organisation was first criticised by naturalists (rejecting the high-tone style) and later by literary scholars (cancelling the annotation level). For our purpose, however, it is a good starting point.

The distinction between technical and aesthetic discourses can help to explain the divergence between desert and mountain perception. The key notion for important sections of the contemporary elite was "improvement." Deserts had to bloom through European style agriculture or through "restoration" of forests, falsely assumed to have covered the regions before pastoralism had "devastated" them. The same technocratic, forest-centric ideology aimed at "restoring" the mountains of the nation, "damaged" by upland pastoralism. This concerned particularly France with its emphasis on territorial homogenisation, yet it permeated other countries as well. ${ }^{36}$ In the mountain case, the negative technical discourse was overshadowed by a much broader aesthetic discourse celebrating the glory of the summits - a central location of sublimity. In the desert case, sublimity, to a certain degree, was a possibility, too. But it was strongly overshadowed by the negative technical view.

36 For Germany, on the Bavarian example: Richard Hölzl, Umkämpfte Wälder: Die Geschichte einer ökologischen Reform in Deutschland 1760-1860 (Frankfurt am Main: Campus, 2010), $16-17,44-48,473-85,496$. 


\section{Bibliography}

\section{Printed Sources}

Göttingische Gelehrte Anzeigen unter der Aufsicht der königl. Gesellschaft der Wissenschaften, 28 December 1809, 2049-2056 (Review of Humboldt 1808).

Humboldt, Alexander von. Ansichten der Natur mit wissenschaftlichen Erläuterungen. Tübingen: J. G. Cotta'scher Verlag, 1808, 1st ed.; Stuttgart: J. G. Cotta'scher Verlag, 1826, 2nd ed.; Stuttgart:J. G. Cotta'scher Verlag, 1849, 3rd ed.

Humboldt, Alexander von. Tableaux de la nature, ou considérations sur les déserts, sur la physionomie des végétaux, et sur les cataractes de l'Orénoque. Translated by J. B. B. Eyriès, 2 vols. Paris: F. Schoell, 1808.

Humboldt, Alexander von. Vues des Cordillères, et Monumens des Peuples indigènes de l'Amérique. Paris: F. Schoell, 1810.

Humboldt, Alexander von. Kosmos: A General Survey of the Physical Phenomena of the Universe. Vol. 1. London: H. Baillière, 1845.

Humboldt, Alexander von. Briefe von Alexander von Humboldt an Christian Carl Josias Freiherr von Bunsen. Leipzig: Brockhaus, 1869 .

Humboldt, Alexander von. Ansichten der Natur, edited by Adolf Meyer-Abbich. Stuttgart: Reclams Universal-Bibliothek, 1969.

Humboldt, Alexander von. Views of Nature. Translated by Mark W. Person, edited by Stephen T. Jackson and Laura Dassow Walls. Chicago, London: University of Chicago Press, 2014.

Humboldt, Alexander von and Aimé Bonpland. Personal Narrative of Travels to the Equinoctial Regions of the New Continent During the Years 1797-1804. Vol. 4. London: Longman, Hurst, Rees, Orme, and Brown, 1819.

Monthly Review 59 (1809), 473-83 (Review of Humboldt 1808).

Rauch, François Antoine. Harmonie hydro-végétale et météorologique, ou recherches sur les moyens de recréer avec nos forêts la force des températures et la régularité des saisons, par des plantations raisonnées. 2 vols. Paris: Levrault, 1802.

\section{Literature}

Berghaus, Heinrich. Physikalischer Atlas zu Alexander von Humboldt, Kosmos. Entwurf einer physischen Weltbeschreibung, edited by Ottmar Ette and Oliver Lubrich. Frankfurt am Main: Eichborn, 2004; 1st ed. 1845-1848.

Biermann, Kurt-R. and Ilse Jahn. Alexander von Humboldt. Chronologische Übersicht über wichtige Daten seines Lebens. Berlin: Akademie-Verlag, 1983.

Cannon, Susan Faye. Science in Culture: The Early Victorian Period. New York: Dawson, 1978. 
Davis, Diana K. Resurrecting the Granary of Rome: Environmental History and French Colonial Expansion in North Africa. Athens: Ohio University Press, 2007.

Davis, Diana K. “Deserts." In The Oxford Handboook of Environmental History, edited by Andrew C. Isenberg, 108-32. New York: Oxford University Press, 2014.

Davis, Diana K. The Arid Lands: History, Power, Knowledge. Cambridge MA: The MIT Press, 2016.

Fiedler, Horst and Ulrike Leitner. Alexander von Humboldts Schriften. Bibliographie der selbständig erschienenen Werke. Berlin: Akademie Verlag, 2000.

Hölzl, Richard. Umkämpfte Wälder: Die Geschichte einer ökologischen Reform in Deutschland 1760-1860. Frankfurt am Main: Campus, 2010.

Hyde, Anne Farrar. An American Vision: Far Western Landscape and National Culture, 1820-1920. New York: New York University Press, 1990.

Krätz, Otto. Alexander von Humboldt: Wissenschaftler - Weltbürger - Revolutionär. Munich: Callwey Verlag, 1997.

Larrère, Raphaël. "Les utopies de François Antoine Rauch: ou comment sortir de la physiocratie, tout en maintenant l'homme dans la nature." In Nouvelles sciences: modèles techniques et pensée politique de Bacon à Condorcet, edited by Franck Tinland, 143-57. Seyssel: Champ Vallon, 1998.

Lubrich, Oliver, ed. Alexander von Humboldt. Das graphische Gesamtwerk. Darmstadt: Lambert Schneider, 2014.

Mack, John. The Sea: A Cultural History. London: Reaktion Books, 2011.

Mathieu, Jon. "Alpenwahrnehmung: Probleme der historischen Periodisierung." In Die Alpen! Zur europäischen Wahrnehmungsgeschichte seit der Renaissance - Les Alpes! Pour une histoire de la perception européenne depuis la Renaissance, edited by Jon Mathieu and Simona Boscani Leoni, 53-72. Bern, Berlin, Bruxelles: Peter Lang, 2005.

Mathieu, Jon. "The Sacralization of Mountains in Europe during the Modern Age." Mountain Research and Development 26, no. 4 (2006): 343-49.

Mathieu, Jon. "Von den Alpen zu den Anden: Alexander von Humboldt und die Gebirgsforschung." In Wissenschaft - Berge - Ideologien. Johann Jakob Scheuchzer (1672-1733) und die frühneuzeitliche Naturforschung-, edited by Simona Boscani Leoni, 293-308. Basel: Schwabe, 2010.

Mathieu, Jon. The Third Dimension: A Comparative History of Mountains in the Modern Era. Cambridge: White Horse Press, 2011.

Richter, Thomas. Alexander von Humboldt: "Ansichten der Natur". Naturforschung zwischen Poetik und Wissenschaft. Tübingen: Stauffenburg, 2009.

Tuan, Yi-Fu. "Desert and Ice: Ambivalent Aesthetics." In Landscape, Natural Beauty and the Arts, edited by Salim Kemal and Ivan Gaskell, 139-57. Cambridge, New York: Cambridge University Press, 1993. 
Whited, Tamara L. Forests and Peasant Politics in Modern France. New Haven: Yale University Press, 2000.

Wulf, Andrea. The Invention of Nature: The Adventures of Alexander von Humboldt, the Lost Hero of Science. London: John Murray, 2015. 